\title{
Trace fossils and ichnofabric in the Kjølby Gaard Marl, uppermost Cretaceous, Denmark
}

\author{
A. A. EKDALE and RICHARD G. BROMLEY
}

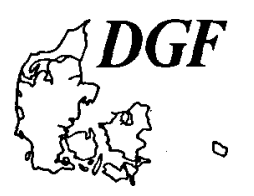

\author{
Ekdale, A. A. \& Bromley, R. G.: Trace fossils and ichnofabric in the Kjølby Gaard Marl, \\ uppermost Cretaceous, Denmark. Bull. geol. Soc. Denmark, vol. 31, pp. 107-119, Copenhagen, \\ March 7th, 1983 \\ https://doi.org/10.37570/bgsd-1982-31-08
}

\begin{abstract}
The Kjølby Gaard Marl (Late Maastrichtian) is a $30 \mathrm{~cm}$-thick, grayish brown, clay-rich, pelagic carbonate unit $\left(75\right.$ to $85 \% \mathrm{CaCO}_{3}$ ) exposed in the Limfjord region of northern Jylland, Denmark. Trace fossil suites and ichnofabric (the sedimentary fabric resulting from all phases of bioturbation) reflect a complex depositional and post-depositional history of the marl unit, which is sandwiched between comparatively pure chalk strata above and below.

Initiation of marl deposition occurred gradually and episodically, as indicated by a micro-styolitic fabric resulting from solution-compaction of finely alternating chalk and clay laminae in the basal portion of the bed. During the major phase of marl deposition represented by the middle and upper parts of the unit, the sea floor apparently was very soft and was colonized by an active infauna which produced a low-diversity suite of trace fossils dominated by horizontal burrows. These are now preserved in a highly compacted ichnofabric which is totally bioturbated but contains no easily identifiable trace fossils. As the sedimentary mode returned to chalk deposition, the marl was buried and subsequently strengthened by compaction sufficiently to allow its colonization by a deeper-burrowing infauna that normally preferred somewhat stiffer, chalky substrates. Thus, the original ichnofabric was modified by the introduction of late-generation, sharply defined and relatively uncompacted "chalk" trace fossils (Thalassinoides, Zoophycos and Chondrites, probably appearing in that order). These are superimposed directly on top of the earlier, highly deformed burrows of the initial trace fossil suite.
\end{abstract}

A. A. Ekdale, Department of Geology and Geophysics, University of Utah, Salt Lake City, Utah 84112, U.S.A.; R. G. Bromley, Institut for historisk Geologi og Palceontologi, Øster Voldgade 10, 1350 København K, Denmark, August 20th, 1982.

Pelagic marine strata of Late Cretaceous age in northwestern Europe typically contain alternating beds of white chalk and light gray or light brown marl. Although chalk/marl sequences are very well-developed in such places as the Cenomanian of southern England and northern France, the Maastrichtian chalk sections of Denmark are remarkably pure in carbonate by comparison, and marl units appear to be developed only locally.

Lower Maastrichtian sediments on the Danish island of Møn contain some rhythms of chalk and marly chalk, but further north the Upper Maastrichtian chalks of eastern Sjælland are 93 to $96 \%$ calcite and contain no significant marls. In northern Jylland, Upper Maastrichtian chalks likewise are very pure (90 to $97 \%$ calcite), but marl and/or marly chalk layers can be seen in the Maastrichtian section at Dania Quarry on Mariager Fjord, for example.

One of the most prominent marls in Denmark is a thin, grayish brown, clay-rich bed occurring about $11.5 \mathrm{~m}$ below the Cretaceous/Tertiary boundary in the small abandoned quarry of
Kjølby Gaard, located north of Limfjorden in northern Jylland (Håkansson \& Hansen 1979). The $30 \mathrm{~cm}$-thick unit, known as the Kjølby Gaard Marl (Troelsen 1955), is not especially important stratigraphically, because it cannot be easily correlated with particular marls at other localities, although it is possibly equivalent to a series of marly beds in Dania Quarry to the southeast. However, the Kjølby Gaard Marl is very interesting sedimentologically, because of the marked change in depositional regime within the Cretaceous chalk sea that it represents, and paleontologically, because of the extraordinarily well-preserved trace fossils that it contains (fig. 1).

This paper describes the trace fossils in the Kjølby Gaard Marl and discusses the paleoecologic and sedimentologic implications of the ichnofabric preserved in the unit.

Color contrasts within the Kjølby Gaard Marl and especially in the underlying and overlying white chalk are rather faint, but we were able to enhance color differences in the sediment by applying lightweight oil to polished surfaces (the 


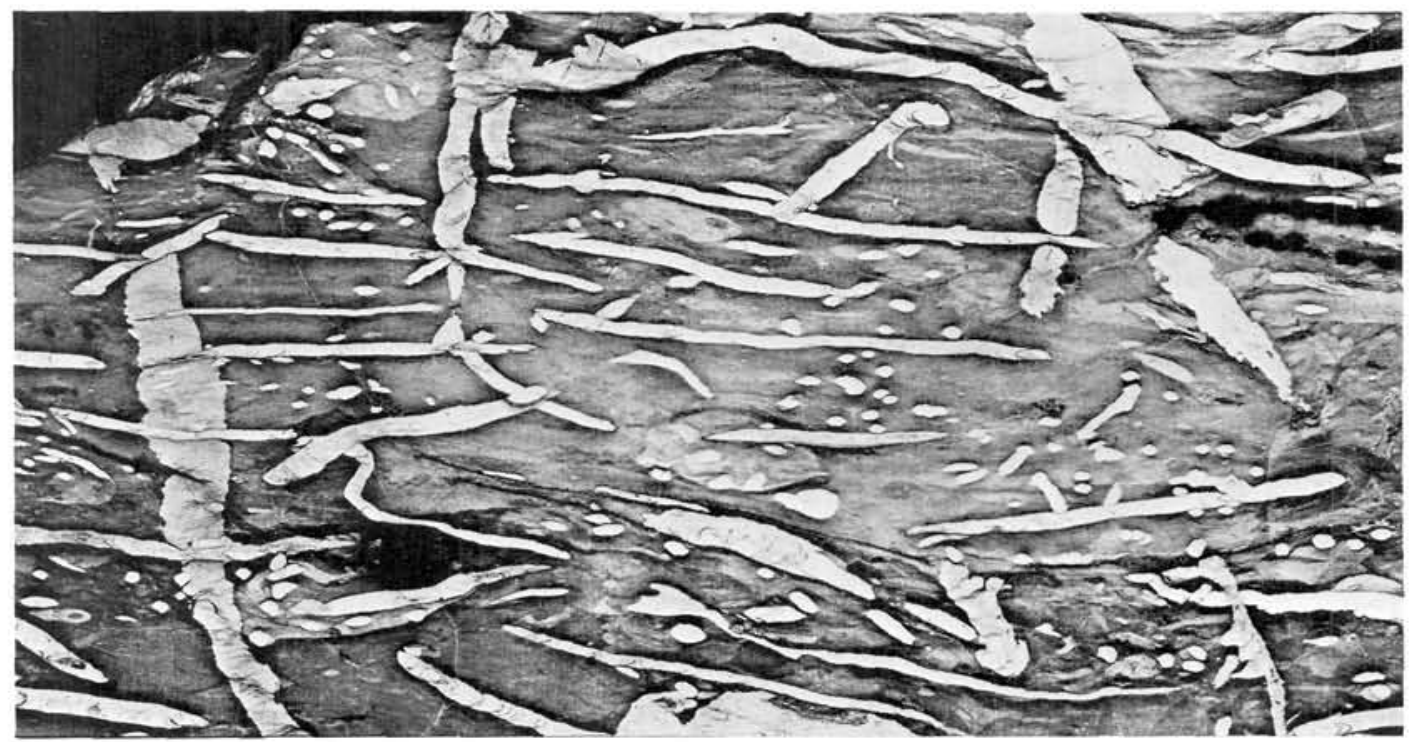

Fig. 1. Abundant and well-preserved Zoophycos (both axial shafts and horizontal spreiten) and Chondrites in middle of Kjølby Gaard Marl (KGM). $\times 0.7$.

"modified Bushinsky oil technique" described by Bromley, 1980). Well-preserved trace fossils and ichnofabrics with all the details of their micro- scopic structure were revealed to us by this method; otherwise, many of the features described in this paper could not be seen at all with the naked eye.

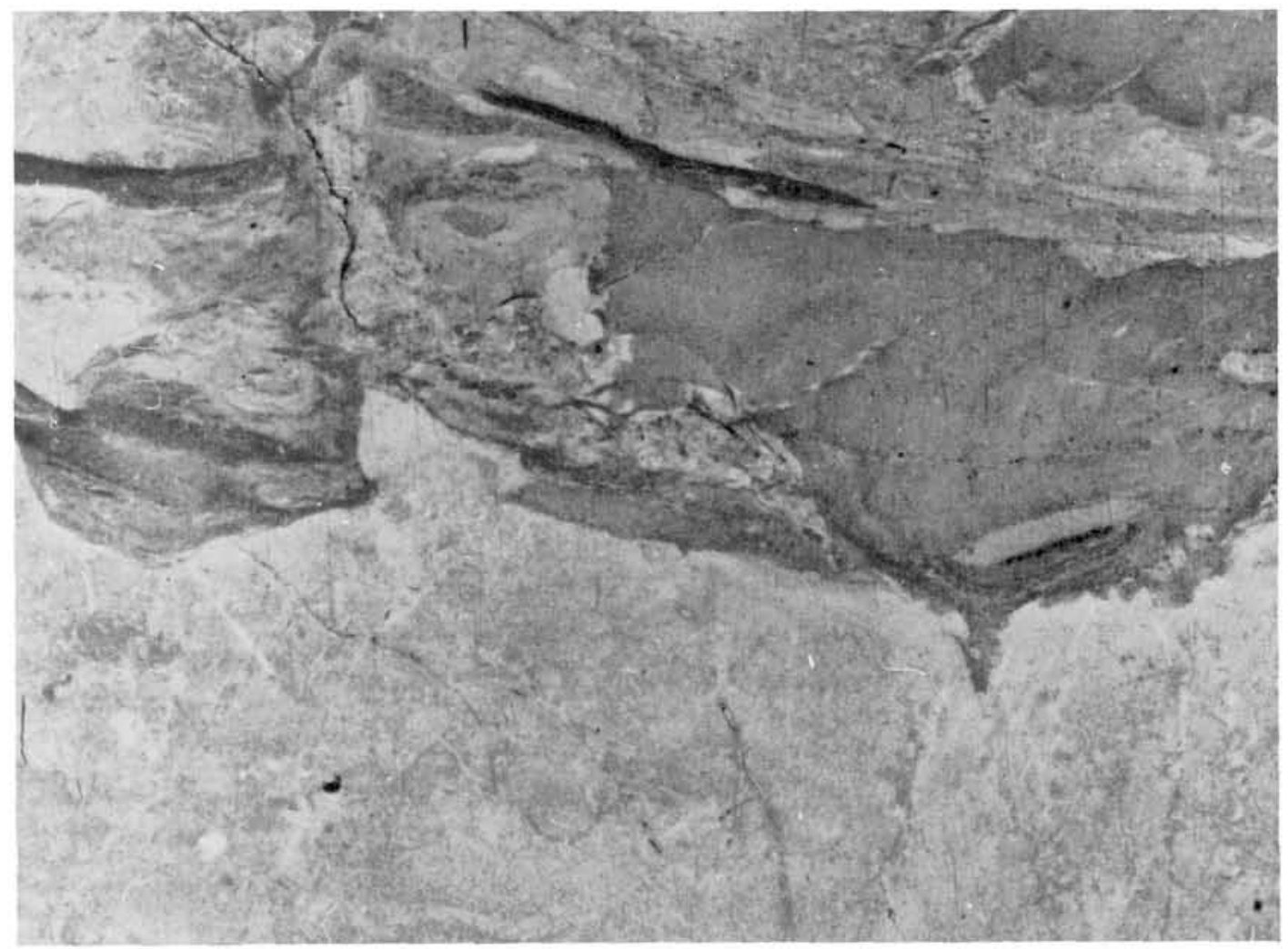

Fig. 2. Irregular boundary between KGM (mottled medium gray) and underlying chalk (light gray). $\times 4$. 


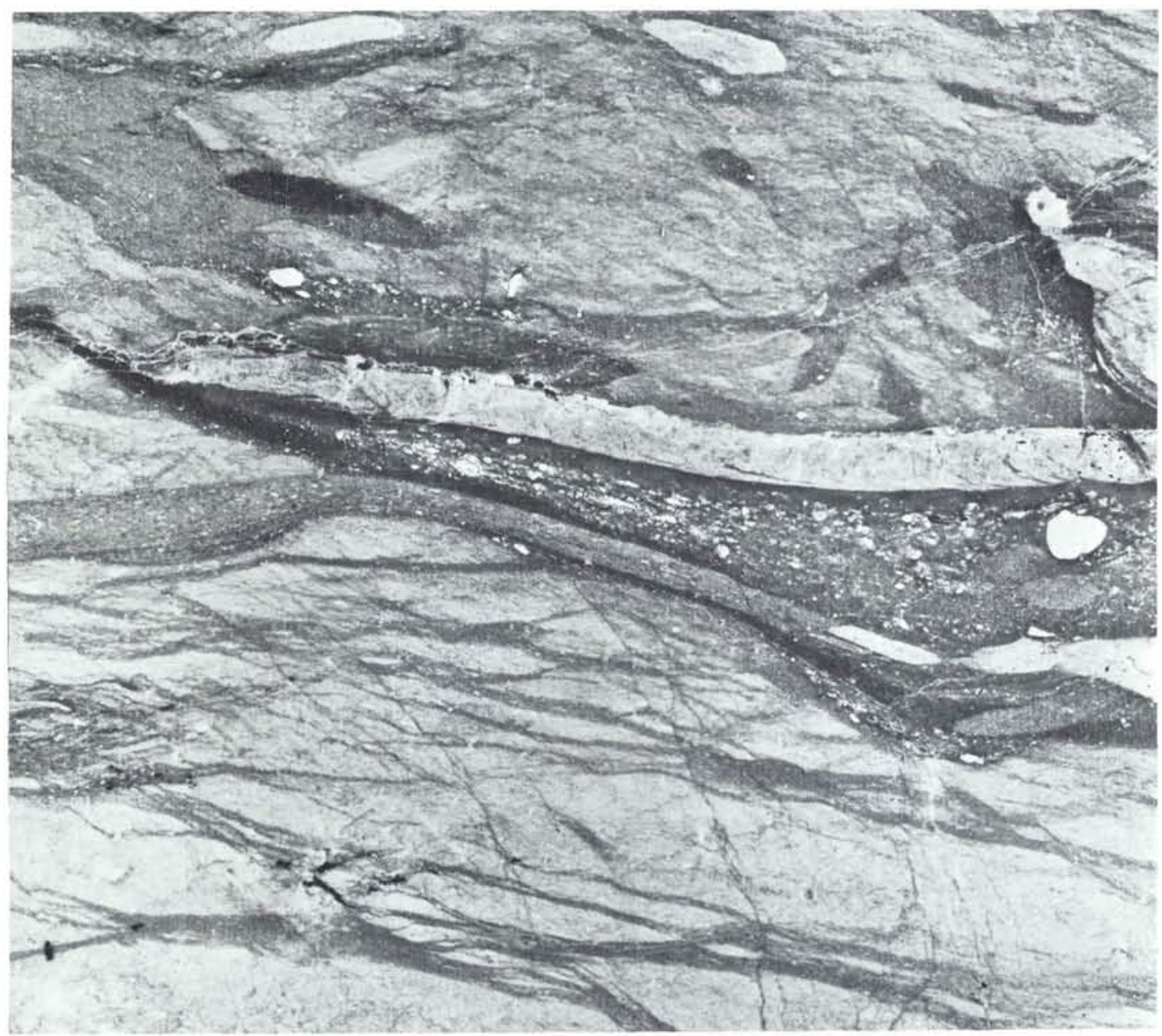

Fig. 3. Basal part of KGM illustrating micro-stylolitic diagenetic fabric in lower part of photo, Zoophycos in middle and Planolites in upper part. $\times 4$.

\section{Lithology}

The Kjølby Gaard Marl is 75 to $85 \% \mathrm{CaCO}_{3}$ with the remaining fraction dominated by clay, and it is bounded above and below by chalk containing about $93 \% \mathrm{CaCO}_{3}$. The upper and lower boundaries between the marl and chalk units are modified by burrowing (fig. 2); it is unlikely that either boundary is erosional. It appears that there was a net increase in the amount of clay (relative to carbonate) introduced to the sea bottom during continuous pelagic sedimentation. No evidence of turbidite of other allochthonous depositional processes in the form of either primary sedimentary structures of detrital grains or clasts, has been observed in the marl.

The dominant coloration of the marl bed is grayish brown, which darkens upward. The lowest one-third of the unit is the lightest-colored part, and the middle is the darkest; the upper part of the bed is only slightly lighter in color than the middle part. Very thin (less than $0.2 \mathrm{~mm}$ thick) anastomosing clay layers in the basal part indicate that sedimentation of the Kjølby Gaard Marl was initiated gradually by episodic deposition of fine clay laminae, which were concentrated by solution-compaction to form a micro-stylolitic diagenetic fabric (fig. 3). This fabric consists of very fine horsetails of marl anastomosing around tiny chalk nodules, and it resembles the larger-scale nodular chalk fabrics described by Kennedy \& Garrison (1975) from southern England. 


\section{General Paleontology}

The Kjølby Gaard Marl apparently occurs within the uppermost Maastrichtian coccolith zone (Micula prinsii Zone) but well beneath the last dinoflagellate zone (Chiropteridium inornatum Zone) of the Maastrichtian (Håkansson \& Hansen 1979; Perch-Nielsen 1979). Foraminifera are common in the marl, and they include the double-keeled planktic form Globotruncana contusa, which does not occur in the pure chalk above and below (Troelsen 1955).

Maastrichtian megafossils are sparse at the Kjølby Gaard locality, and only a few species of bryozoans, bivalves, echinoids and ammonites have been reported (Håkansson \& Hansen 1979). In the course of this research, no body fossils or skeletal fragments of macroinvertebrates were found in the Kjølby Gaard Marl itself.

\section{Ichnology}

The ichnology of a sedimentary deposit includes the ichnotaxa (identifiable trace fossils), ichnofacies (naturally occurring groups of trace fossils as reflections of the depositional environment) and ichnofabric (those aspects of the texture and internal structure of the bed resulting from all phases of bioturbation). An ichnofabric may simply reflect a single bioturbation event; or alternatively several suites of trace fossils, possibly representing different ichnofacies, may be emplaced in a given sediment at different times to produce a complex, multi-phase ichnofabric.

The Maastrichtian chalk which underlies and overlies the Kjølby Gaard Marl exhibits a totally bioturbated ichnofabric (Bromley \& Ekdale 1982), and contains a suite of trace fossils typical of chalks all over northern Europe (Bromley

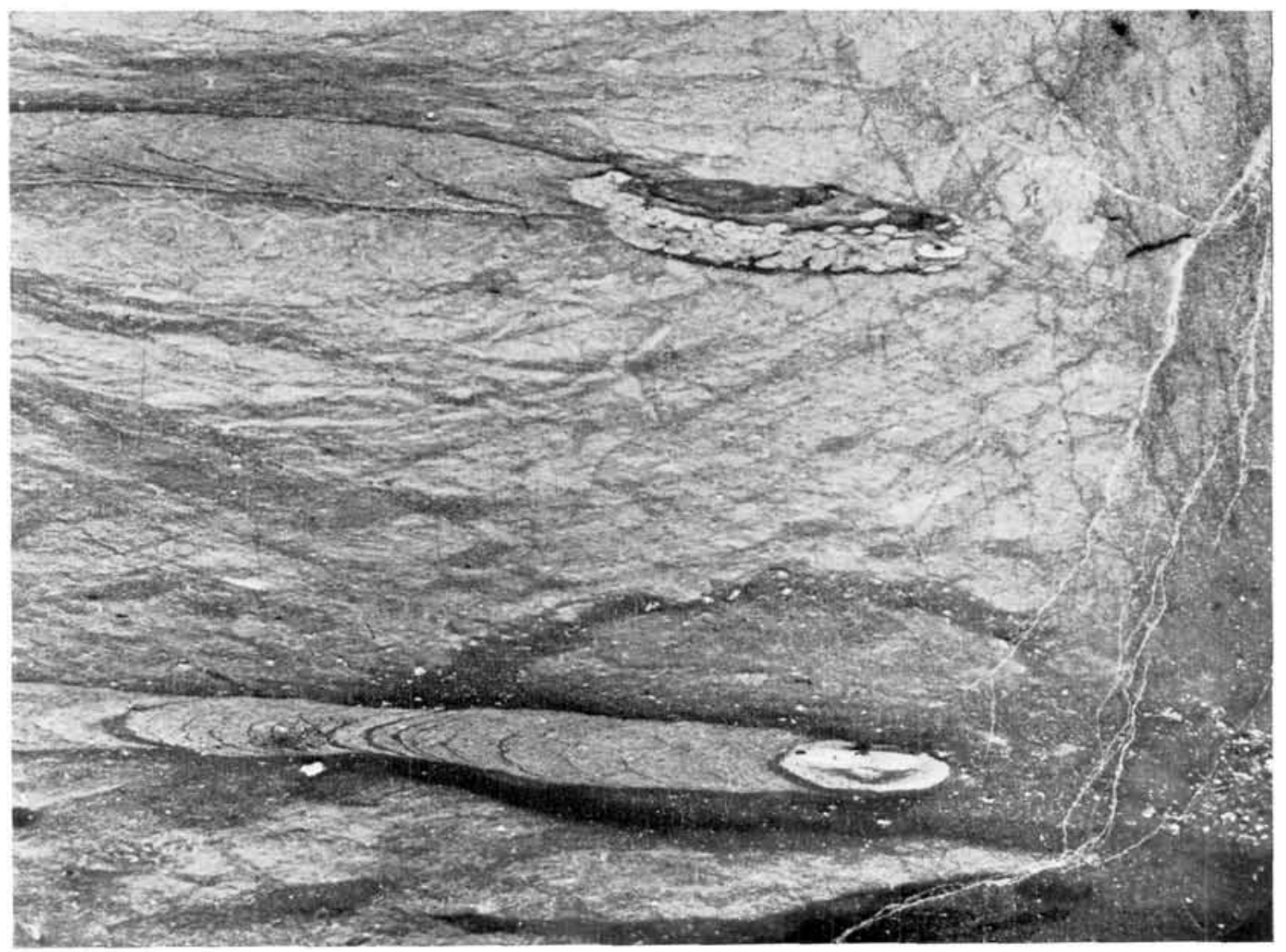

Fig. 4. Basal part of KGM containing late-stage Zoophycos juxtaposed on early-stage ichnofabric of highly compacted Planolites. Note the re-burrowing of the marginal tubes in both Zoophycos specimens with Chondrites. $\times 4$. 


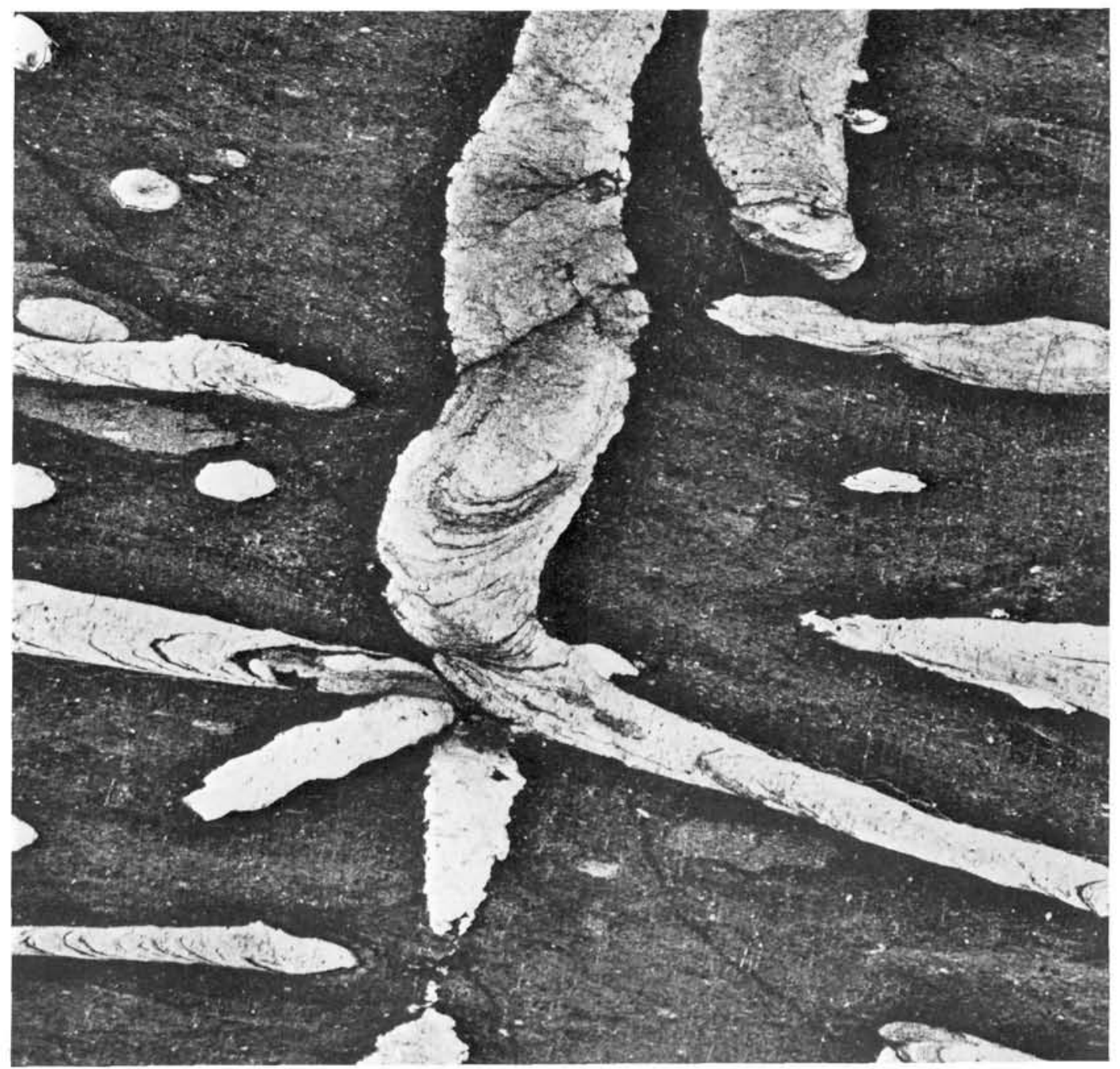

Fig. 5. Axial shaft and horizontal spreiten of Zoophycos and tunnels of Chondrites in middle of KGM. $\times 5$.

1967; Kennedy 1967, 1970, 1975). Zoophycos and Chondrites are abundant in the pure chalk, and vertical shafts (?Skolithos) are not uncommon.

The marl itself likewise contains characteristic "chalk" trace fossils, but they are much more abundant and diverse than in the pure white chalk. This is due either to preservational (i.e., visibility) differences or to real differences between the original infauna of the marly and chalky substrates. We have no way of deciding with certainty which is the case, but we strongly suspect the truth to contain elements of both.

Although only one-third of a meter thick, the Kjølby Gaard Marl exhibits vertical transitions in its ichnofacies and ichnofabric. The basal portion of the marl contains sharply defined Zoophycos with distinct marginal tubes and chevron-patterned spreiten overprinted on a smeared ichnofabric containing relatively indistinct trace fossils, probably mostly Planolites (fig. 4).

Trace fossil diversity increases upward near the darker-colored center of the marl bed and remains large throughout the remainder of the unit. Zoophycos and Chondrites are extremely abundant in the center of the unit (fig. 5), and they are accompanied by Thalassinoides and Planolites. The micro-stylolitic net fabric that characterizes the basal region is not visible in the center of the marl, but the background ichnofabric of smeared 


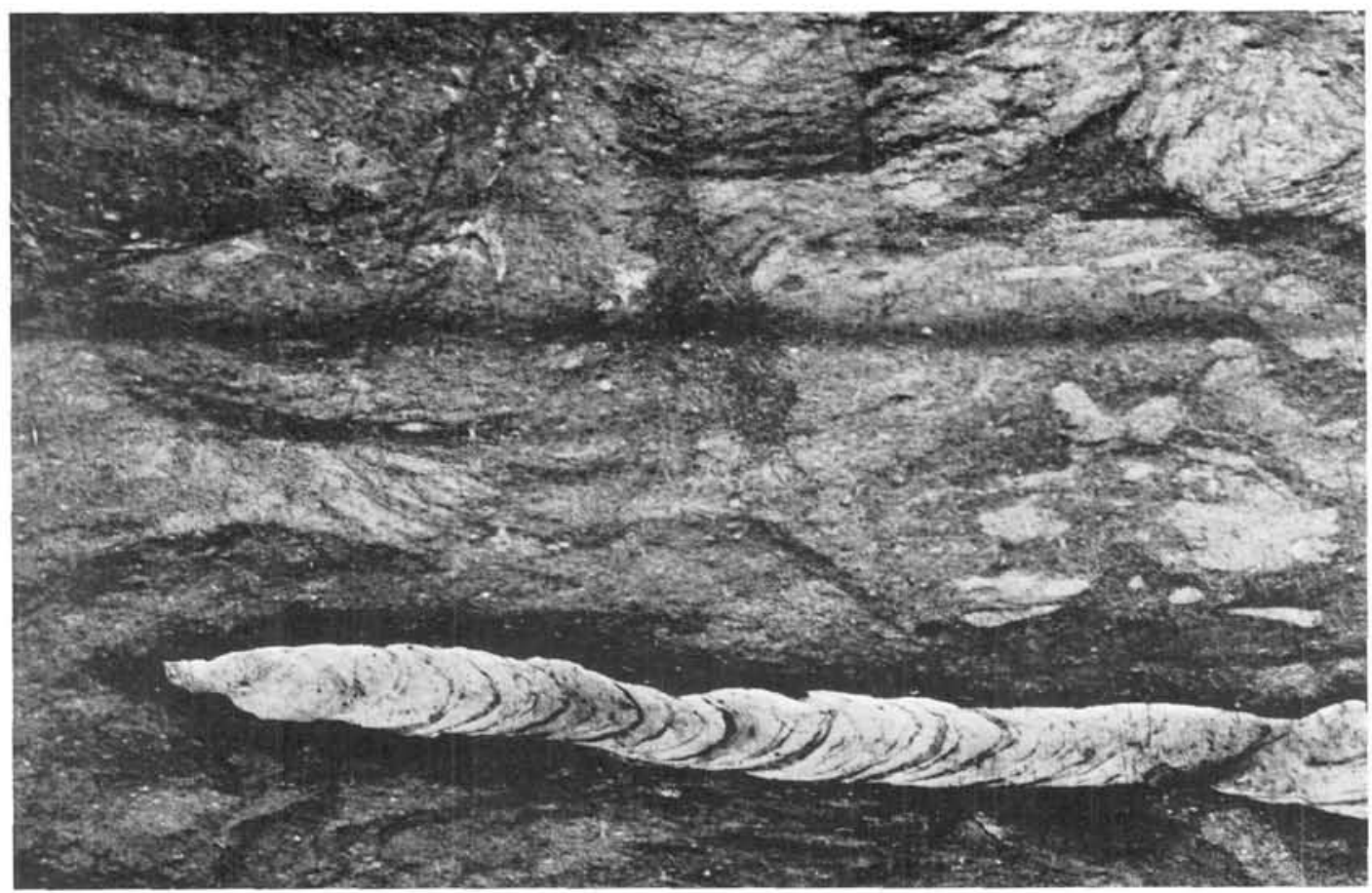

Fig. 6. Sharply defined Zoophycos on a smeared, totally bioturbated, background ichnofabric in middle of KGM. $\times 5$. (Note: The horizontal black line across the figure is an artifact.)

Planolites is evident (fig. 6). The juxtaposition of trace fossils presents a kaleidoscope of color shades (fig. 7); indeed, so many successive bioturbation events have occurred in this sediment that it is impossible to count them accurately.

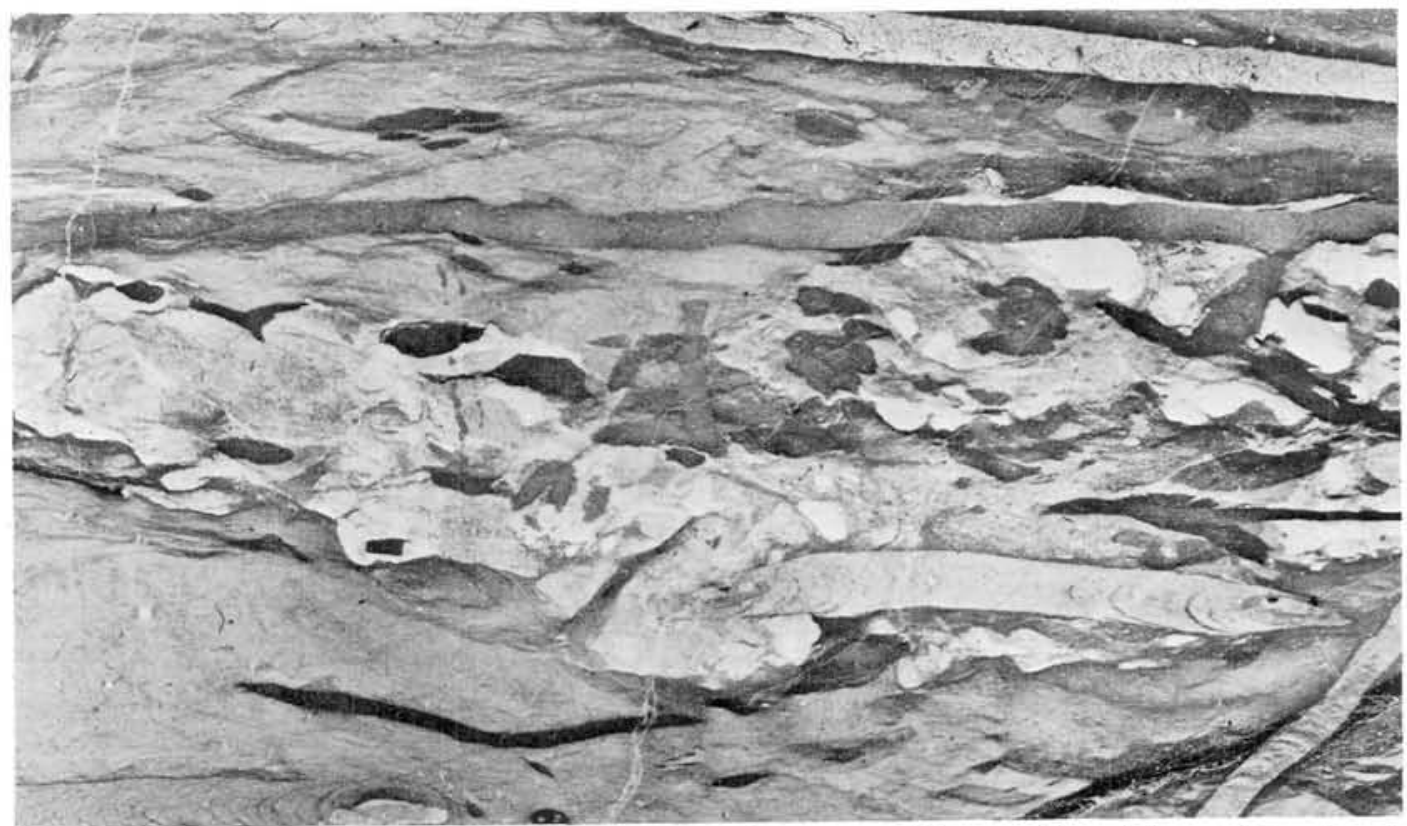

Fig. 7. Juxtaposition of many different generations of burrows, including two types (light gray and very dark gray) of Zoophycos, in middle of $K G M$. $\times 2$. 


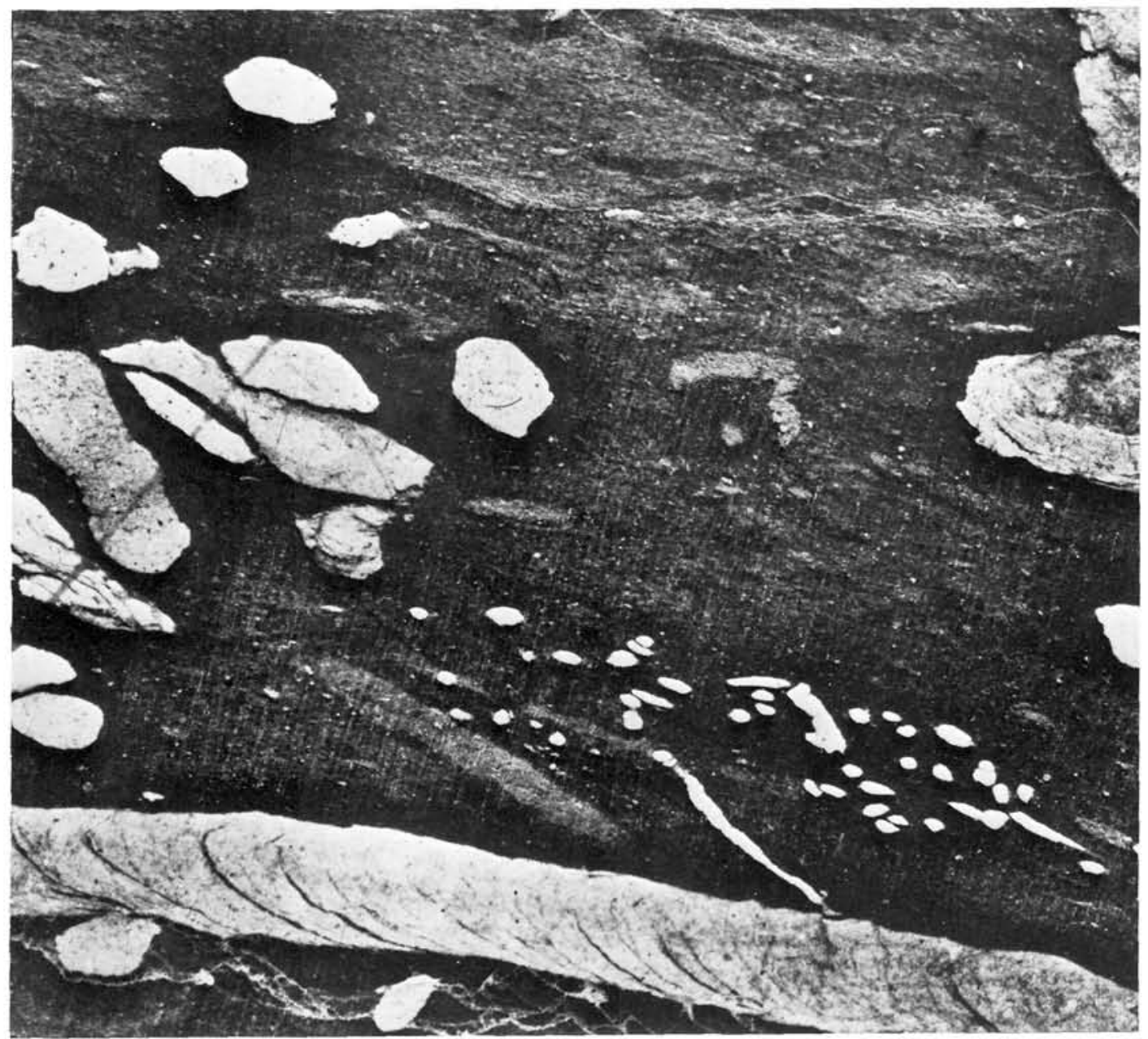

Fig. 8. Large (upper left) and small (lower right) forms of Chondrites in middle of KGM. (Enlargement of part of fig, 9.) $\times 5$.

\section{Chondrites}

The highly branching burrow system Chondrites is a very prominent trace fossil in the dark central and upper portions of the Kjølby Gaard Marl (fig. $8)$. It is very light in color (usually whiter, in fact, than Zoophycos and all the other trace fossils) and possesses very sharply defined burrow margins. The branching tunnels that compose the burrow system are virtually unaffected by compaction, and no internal structure (e.g., pellets or meniscae) of the burrow-fill material is apparent.

There are two types of Chondrites, which are distinguished more on the basis of size than morphology (fig. 8). The larger variety has tunnel diameters of slightly less than $2 \mathrm{~mm}$; the smaller type possesses tunnels about $0.3 \mathrm{~mm}$ in diameter. The larger form is much more widespread than the smaller one, which occurs only in localized, often lens-shaped, patches.

\section{Planolites}

Unbranched, unornamented burrows that occur primarily in a horizontal or subhorizontal plane are generally referred to Planolites. In the Kjølby Gaard Marl there are abundant subhorizontal burrows that were emplaced in a very soft sediment and are now so highly compacted that accurate assessment of their original total morphology is rendered difficult (fig. 3). Because 
they closely resemble burrows identified as Planolites in clay-rich deep-sea deposits (Ekdale 1977, 1980) and shelf-sea chalks (Kennedy 1975), we assign these trace fossils at Kjølby Gaard to the same ichnogenus.

\section{Skolithos}

Simple vertical shafts are present in sparse numbers in the chalk that underlies the Kjølby Gaard Marl, but none were observed in the marl bed itself. The shafts in the chalk are small, typically $3 \mathrm{~mm}$ or less in diameter, and they contain sharp burrow walls which, however, may be surrounded in some cases by fuzzy, discolored zones in the adjoining matrix sediment. These burrows contain no obvious external sculpture or internal structure. Although we have not seen natural upper or lower terminations of these vertical shafts, in this report we refer them to?Skolithos.

\section{Thalassinoides}

One of the most abundant and characteristic ichnogenera in the European chalk is Thalassinoides, which is a large anastomosing system constructed presumably as a semi-permanent dwelling/feeding burrow for decapod crustaceans (Bromley 1967; Kennedy 1967). Thalassinoides

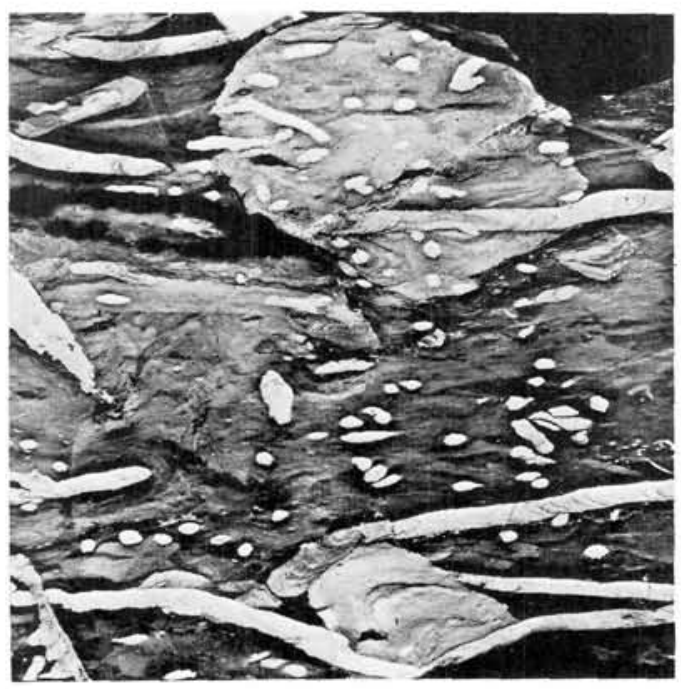

Fig. 9. Thalassinoides, at top and bottom of figure, cutting the smeared, early ichnofabric and themselves cut by pale Zoophycos and Chondrites, in middle of KGM. $\times 0.7$. is very common in the Maastrichtian chalk of Denmark, including that at Kjølby Gaard, but it is not particularly abundant within the Kjølby Gaard Marl itself. The horizontal geometry of branching networks of Thalassinoides is not observable at the Kjølby Gaard site due to the lack of exposed bedding planes, and vertical sections do not allow detailed descriptions at the ichnospecies level.

Preservation quality of identifiable Thalassinoides and cross-cutting relationships of different ichnotaxa (fig. 9) demonstrate that Thalassinoides occurred approximately in the middle of the bioturbation sequence (i.e., following emplacement of abundant Planolites but prior to the introduction of Chondrites and Zoophycos).

\section{Zoophycos}

The complex burrow system Zoophycos is abundant in the Maastrichtian of Denmark, and an observer's visual impression of the Kjølby Gaard Marl is dominated by the horizontally striped pattern created by the marked tiering of light-colored Zoophycos spreiten (fig. 1), which generally are about $2 \mathrm{~mm}$ thick and are spaced about $1 \mathrm{~cm}$ apart. In plan view, the spreiten consist of densely packed arcuate tunnel walls radiating from an axial region. There are no secondary structures (the "minor lamellae" of Simpson, 1970) connecting the radiating tunnels, as occur in many forms of Zoophycos elsewhere, especially in continental slope deposits (Wetzel \& Werner 1981). This simpler burrow morphology of the Kjølby Gaard Zoophycos is consistent with that observed in Zoophycos in deep-sea pelagic deposits (Ekdale 1977), although the Kjølby Gaard Zoophycos spreiten are not obviously pelleted, as are many of the deep-sea forms.

In a cross-sectional view, the Zoophycos spreite is composed of closely spaced chevrons. Commonly the spreite is cut by later burrows, such as Chondrites and other Zoophycos. In some cases a Zoophycos appears to be preferentially re-burrowed, commonly by a densely packed Chondrites-like trace fossil in the marginal tube (fig. 4) or by a tubular backfilled burrow that penetrates and moves horizontally through the middle of the Zoophycos spreite.

Zoophycos typically is very light-colored in the 


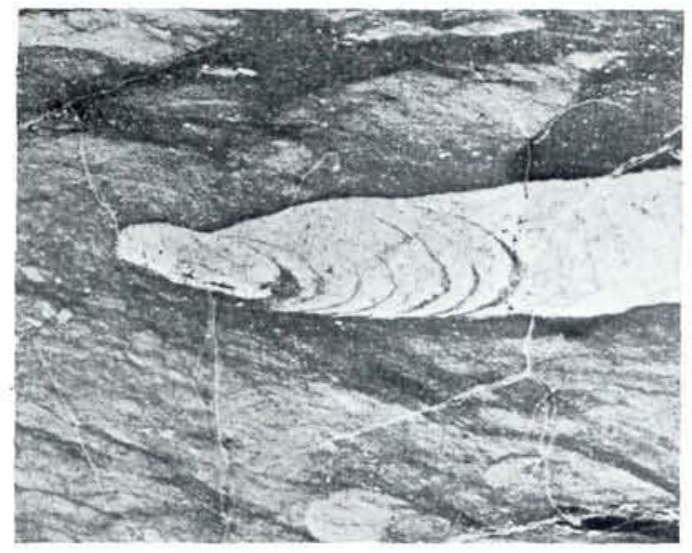

Fig. 10. Lower part of KGM illustrating the small size of the marginal tube of a light-colored Zoophycos relative to the rest of its spreite. $\times 4$.

dark central part of the marl bed, but lower down very dark-colored Zoophycos are visible in the transitional region between the base and center of the bed (fig. 7). In every case where the two types of Zoophycos are associated, the lighter form cuts across the darker form and thus post-dates it. Moreover, the lighter forms always look fresher than the darker ones, which invariably are more severely compacted and commonly lack a sharply defined chevron structure within their spreiten. The light-colored forms actually may differ from the dark ones taxonomically, because their spreiten are more obviously lobate, as demonstrated by the large number of short, double-ended spreite cross-sections which are visible in vertical faces of samples.

The marginal tube is quite visible in the light-colored Zoophycos from Kjølby Gaard, but in no case did we see an organic-rich or pyritic fill in it that could have represented the remains of the burrowing animal. It is noteworthy, however, that the marginal tube is always slightly smaller in height (i.e., compacted diameter) than the rest of the spreite (figs. 6, 7 and 10).

The spreite of many Zoophycos specimens terminates in a retrusive Teichichnus-like structure at the site of the marginal tube (fig. 11). Presumably this is an indication that the spreite had reached its maximum lateral extent but that the burrowing organism continued to occupy its marginal position for some time, even though it had ceased expanding the dimensions of its burrow system. In all cases this Teichichnus-like structure was retrusive, and in no case did we observe an ostensible obstacle in the sediment to prevent further expansion of the spreite.

\section{Discussion}

The Kjølby Gaard Marl represents a local sedimentation event during which the amount of clay entering this region of the Maastrichtian chalk sea increased. There is no compelling evidence to suggest detrital influx of terrigenous clay from laterally adjoining source areas, so we believe the clay had a pelagic origin.

The micro-stylolitic net fabric in the lower part of the unit probably derives from original alternating fine clay and chalk seams. This suggests that there was a somewhat spasmodic transition from pure chalk deposition below the marl unit to the dominantly marl deposition of the central and upper parts of the unit. This transition could have been caused by a gradual, temporary shallowing of the lysocline and possibly also calcite compensation depth (CCD). If so, the episodic nature of the lower layers within the Kjølby Gaard Marl indicates that those beds would have been deposited at a water depth very close to the lysocline. A rise in the level of the lysocline more than likely would be subject to very small-scale fluctuations, which could have caused short-term alternation between chalk and clay deposition for a brief period until the lysocline had risen significantly higher than the water depth at this site and pure calcareous ooze had ceased to accumulate.

A temporary rise in the lysocline, however, does not explain the unique appearance at this level of the special planktic fauna noted by Troelsen (1955). Other possible mechanisms for increasing the relative amount of clay deposited on the sea floor include a localized temporary drop in the productivity of calcareous nannoplankton, a short-term eustatic sea-level rise, a tectonic subsidence in this portion of the basin, a sudden increase in the amount of airborne terrigenous material entering the pelagic depositional system in this area, or any combination of the above.

The uppermost part of the Kjølby Gaard Marl does not exhibit a reverse of the basal part; that is, we do not see a similar micro-stylolitic net fabric at the top of the bed with the chalk content 


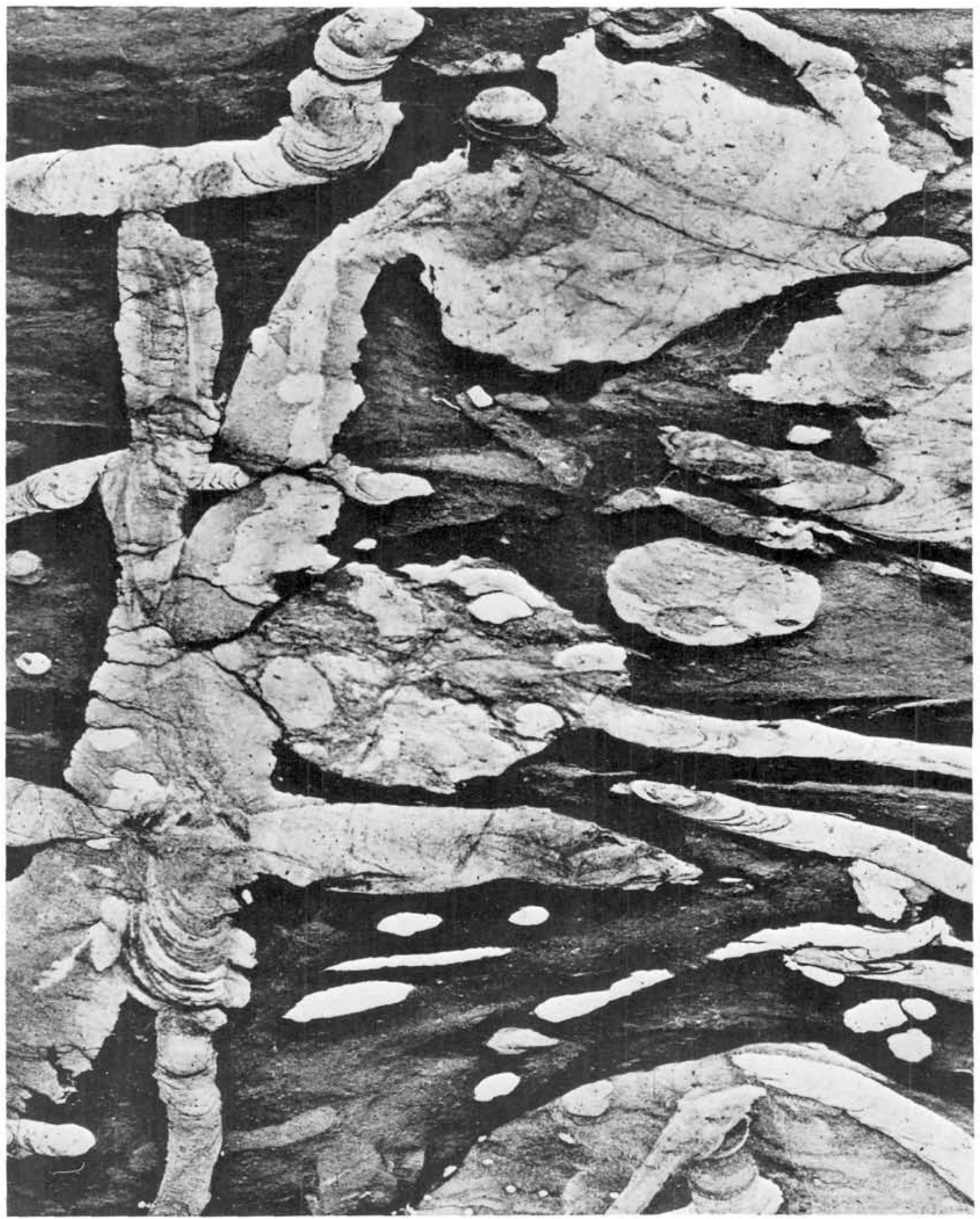

Fig. 11. Middle part of KGM illustrating complex crosscutting relationships of Thalassinoides, Zoophycos and Chondrites. Note the peculiar Teichichnus-like structures at the sites of the marginal tubes of several Zoophycos spreiten. $\times 3$.

gradually increasing upward into the relatively pure chalk that overlies the entire unit. This means that the lysocline probably fell more rapidly than it rose.
The ichnology of the Kjølby Gaard Marl is not straightforward, because several different suites of burrows are superimposed on one another. In general, there appear to be two major trace fossil 
suites, possibly reflecting different ichnofacies, which are juxtaposed on each other to create a complex ichnofabric. The earliest suite is represented by the compacted and smeared fabric of flattened Planolites that forms the totally bioturbated background on which a later suite of distinct and relatively uncompacted burrows is juxtaposed.

The first trace fossil suite represents the initial bioturbation of the marly substrate. Because of its relatively high clay content, this original sediment was much less cohesive than pure carbonate. The ichnofacies observed in cores of deep-sea clay differs from that of calcareous ooze by containing a low-diversity assemblage of dominantly horizontal trace fossils which are commonly deformed by compaction and soft-sediment movements (Ekdale \& Berger 1978; Ekdale 1980). The dearth of vertical burrows (e.g., Skolithos) and elaborately organized burrow systems (e.g., Chondrites and Zoophycos) in clay-rich deposits in the deep sea is due partly to the ease of burrow destruction in a very soft substrate after the burrow is vacated by its creator and partly to the inability of infaunal creatures to construct certain kinds of structures if the sediment is too soupy.

The Kjølby Gaard Marl certainly was not an abyssal red clay, because it does contain a fairly high amount of carbonate $\left(75\right.$ to $\left.85 \% \mathrm{CaCO}_{3}\right)$. However, the initial burrow suite and its associated ichnofabric exhibit the characteristics of trace fossils in a sub-lysoclinal, clay-rich habitat. The sediment is totally bioturbated, but the trace fossils are so highly deformed that there is no way of discerning how many generations of burrows are present. The burrows have a dominantly horizontal orientation, and most fall within the typical size range of deep-sea Planolites (i.e., approximately 0.5 to $2.0 \mathrm{~cm}$ in original diameter), although their true morphology cannot be determined accurately. Some may have been Thalassinoides; however, no vertical shafts, spreiten burrows or branching burrow systems are evident in this trace fossil suite.

Subsequently, a typical suite of chalk trace fossils dominated by Zoophycos and Chondrites (at least two varieties of each) was introduced. These trace fossils are remarkably well-preserved relative to those of the earlier suite on which they are overprinted. They exhibit almost no compaction or shear deformation, and there is very sharp definition of their burrow margins and (in the case of Zoophycos) internal structure. The types of burrows and quality of their preservation are more characteristic of chalk than of marl, and we suggest that such trace fossils probably would not be found deep within a thicker marl unit. This is because they are indeed chalk trace fossils that have been produced within the marl long after the endemic marl ichnofauna had ceased to be emplaced.

Zoophycos-producing and Chondrites-producing animals, who may have been unable to operate in the original marly substrate because of its weak physical properties, entered and occupied the marl layer after it had been strengthened by compaction and partial de-watering. Thus, we see an exotic suite of "chalk" burrows occuring anomalously in a marl that became chalk-like in its physical properties.

In order to discover possible chemical differences between the material contained in Zoophycos spreiten and that in the surrounding marl, several light-colored spreiten were sampled from the dark central and upper parts of the marl bed for carbon analysis on a LECO WR-12 carbon determinator. The Zoophycos contained 88 to $91 \% \mathrm{CaCO}_{3}$ and 0.0 to $0.4 \%$ organic carbon; the adjacent marl contained 76 to $80 \% \mathrm{CaCO}_{3}$ and 0.2 to $0.4 \%$ organic carbon; and samples of white chalk collected from immediately below and above the marl bed contained $93 \% \mathrm{CaCO}_{3}$ and $0.1 \%$ organic carbon. Thus, the Zoophycos here do not represent appreciable concentrations of organic carbon, as might be expected if they were packed with fecal material. Furthermore, the fact that the $\mathrm{CaCO}_{3}$ content (and color) of the spreiten is intermediate between those of the marl and the overlying chalk suggests that at least some Zoophycos act as conduits for vertical mixing of sediment, in this case chalk which is piped down into the marl from above.

Chondrites likewise served as a means for allowing downward transfer of sediment from overlying strata. Both types (sizes) of Chondrites can be observed cutting across every other kind of trace fossil in the Kjølby Gaard Marl; only in very rare instances is it cut by another burrow, and then only by a very fresh-looking Zoophycos. Chondrites therefore represents the last bioturbation event. As with Zoophycos, Chondrites 
probably was constructed by a deep-burrowing animal rather late in the post-depositional history of the sediment, when it was somewhat stiff but still uncemented.

Because the light-colored filling of Chondrites and at least some Zoophycos burrows most likely derives from the chalk above the marl bed, the creators of both ichnogenera originated their burrows after the Kjølby Gaard Marl had been buried beneath later chalky deposits. Thus, actually, they can be thought of as members of the chalk community which have penetrated the substrate deep enough to be preserved in the marl. The two trace fossils really are closely associated in time of construction, as indicated by their similarly excellent states of preservation and the fact that a few Zoophycos can be found superimposed on Chondrites.

A specimen of Thalassinoides from the dark central part of the marl contains light gray burrow-fill material that is horizontally laminated in the lower half of the tunnel (fig. 12). In this respect the burrow is reminiscent of the Thalassinoides in the English Cenomanian chalk described by Kennedy $(1967,1970)$, which also have a partial fill of laminated sediment. The Kjølby Gaard specimen is the only clear evidence of undisturbed primary stratification that we discovered in the entire marl unit, and it is significant that it occurs inside a relatively large burrow that probably served as a semi-permanent dwelling structure of a crustacean.

The Thalassinoides with laminated fill was constructed in the marl after the production of the original trace fossil suite, and it was maintained as an open burrow with firm walls. Following evacuation of the burrow by its creator, it was passively filled from above with sediment that was richer in carbonate than the surrounding marl; alternating light and dark laminae indicate a quiet, episodic mode of sedimentation. The upper half of the burrow-fill material is neither evenly stratified nor clearly burrowed; perhaps it was bioturbated (but not totally homogenized) by very tiny burrowers, yielding a slightly disturbed ichnofabric containing no distinct burrows.

The Thalassinoides fill probably was emplaced too deeply beneath the sea floor to be affected by early Planolites-suite bioturbation, but sufficiently shallowly to be cut by Zoophycos and Chondrites. This indicates that Thalassinoides in the Kjølby Gaard Marl was emplaced at depths intermediate between the Planolites suite and the Zoophycos-Chondrites suite.

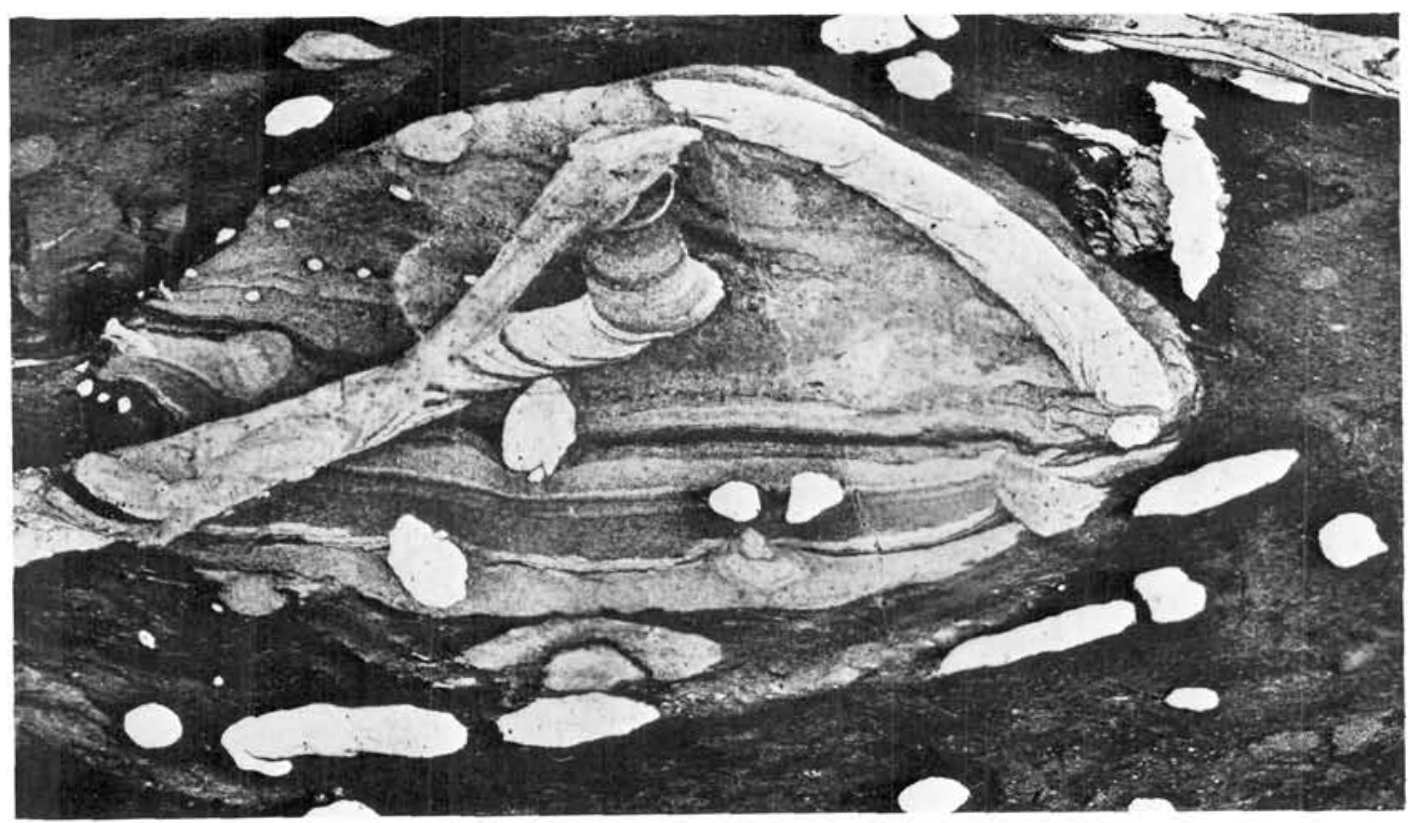

Fig. 12. Thalassinoides burrow-fill in middle of KGM. Note the distinct primary lamination preserved in the lower half of the burrow and the indistinct background fabric in the upper half of the burrow. Also note that the Thalassinoides burrow-fill is re-burrowed by both types of Chondrites as well as Zoophycos (one specimen of which possesses a Teichichnus-like structure at the site of the marginal tube and which is itself re-burrowed by another Zoophycos). $\times 3$. 


\section{Conclusions}

Analysis of trace fossils, ichnofabrics and other sedimentary features in the Kjølby Gaard Marl indicates that it possesses a complex depositional and early post-depositional history. As marl sedimentation was introduced (apparently episodically), the sea floor apparently became softer and weaker than the relatively pure calcareous sea bottom that had preceded it. The marly sea bottom was colonized by an active infauna that produced a totally bioturbated ichnofabric containing abundant horizontal burrows, which are now highly deformed. Following the return to chalk sedimentation, the marl bed was buried, compacted and thus strengthened sufficiently to allow its colonization by burrowers that normally preferred stiffer, calcareous sediment. This second phase of bioturbation yielded a trace fossil suite characterized by sharply defined, uncompacted Zoophycos and Chondrites. Thus, the Kjølby Gaard Marl contains a complex ichnofabric developed during two phases of bioturbation and represented by two superimposed suites of trace fossils. It now remains to be seen to what extent this situation may be true of the chalk in general, where the earlier suite is normally barely visible owing to the chemical purity of the sediment.

Acknowledgments. This research was funded primarily by a grant to Ekdale from the Division of Earth Sciences, National Science Foundation, Washington, D.C. In addition, facilities and miscellaneous supplies were made available by the Institut for historisk Geologi og Palæontologi, Københavns Universitet, where the project was initiated during a sabbatical leave by Ekdale from University of Utah. The authors especially wish to thank Jan Aagaard and Peter Eilertsen for their expert photographic assistance.

\section{Dansk sammendrag}

Kjalby Gaard merglen er en ca. $30 \mathrm{~cm}$ tyk, gråbrun, lerrig horisont $\mathrm{i}$ toppen af skrivekridtet i Thy, som er usædvanligt rig på sporfossiler. Behandling med let maskinolje fremhæver sporfossiler med stor kontrast, hvilket muliggør en detaljeret undersøgelse af det stærkt kompakterede sediments "fabrik". To sporfossil selskaber har kunnet udskilles: et tidligt, kompakteret Planolites selskab og et senere, non-kompakteret Zoophycos-Chondrites selskab. Kun det sene selskab kan normalt erkendes $i$ det rene skrivekridt.

\section{References}

Bromley, R. G. 1967: Some observations of burrows of thalassinidean Crustacea in chalk hardgrounds. Quart. J. geol. Soc. London 123: 157-182.

Bromley, R. G. 1980: Enhancement of visibility of structures in marly chalk: modification of the Bushinsky oil technique. Bull. geol. Soc. Denmark 29: 111-118.

Bromley, R. G. \& Ekdale, A. A. 1982: Trace fossils and ichnofabrics associated with the Cretaceous-Tertiary transition in Denmark. Abstracts intl. Assoc. Sedimentol. 3rd European Mtg., Copenhagen 1982: 114-116.

Ekdale, A. A. 1977: Abyssal trace fossils in worldwide Deep Sea Drilling Project cores. In Crimes, T. P. \& Harper, J. C. (editors): Trace Fossils II. Seel House Press: Liverpool, 163-182.

Ekdale, A. A. 1980: Trace fossils in Deep Sea Drilling Project Leg 58 cores. Init. Rpts. Deep Sea Drilling Proj. 58: $601-605$.

Ekdale, A. A. \& Berger, W. H. 1978: Deep-sea ichnofacies: modern organism on and in pelagic carbonates of the western equatorial Pacific. Palaeogeogr., Palaeoclimatol., Palaeoecol. 23: 263-278.

Håkansson, E. \& Hansen, J. M. 1979: Guide to Maastrichtian and Danian boundary strata in Jylland. In Birkelund, T. \& Bromley,. R. G. (editors): Cretaceous-Tertiary Boundary Events Symposium I: 171-188. Copenhagen.

Hansen, J. M. 1977: Dinoflagellate stratigraphy and echinoid distribution in Upper Maastrichtian and Danian deposits from Denmark. Bull. geol. Soc, Denmark 26: 1-26.

Kennedy, W. J. 1967: Burrows and surface traces from the Lower Chalk of southern England. Bull. British Museum (nat. Hist.), Geology 15: 125-167.

Kennedy, W. J. 1970: Trace fossils in the chalk environment. In Crimes, T. P. \& Harper, J. C. (editors): Trace Fossils. Seel House Press: Liverpool, 263-282.

Kenndy, W. J. 1975: Trace fossils in carbonate rocks. In Frey, R. W. (editor): The Study of Trace Fossils. Springer: New York, 377-398.

Kennedy, W. J. \& Garrison, R. E. 1975: Morphology and genesis of nodular chalks and hardgrounds in the Upper Cretaceous of southern England. Sedimentol. 22: 311386.

Perch-Nielsen, K. 1979: Calcareous nannofossils in Cretaceous-Tertiary boundary sections in Denmark. In Christensen, W. K. \& Birkelund, T. (editors): Cretaceous-Tertiary Boundary Events Symposium II: 120-126. Copenhagen.

Simpson, S. 1970: Notes on Zoophycos and Spirophyton. In Crimes, T. P. \& Harper, J. C. (editors): Trace fossils. Seel House Press: Liverpool, 505-514.

Troelsen, J. C. 1955: Globotruncana contusa in the white chalk. Micropaleontol. 1: 76-82.

Wetzel, A. \& Werner, F. 1981: Morphology and ecological significance of Zoophycos in deep-sea sediments off NW Africa. Palaeogeogr., Palaeoclimatol., Palaeoecol. 32: $185-212$. 